\title{
URSOLIC ACID FROM Rhododendron ungernii
}

G. E. Dekánosidze

UDC 547.972

Triterpene compounds have been detected in many species of the genus Rhododendron [1-3].

We have investigated for their ursolic acid content the leaves of an evergreen shrub widely distributed in southern Georgia, Rhododendron ungernii Trautv. (family Ericaceae), collected in July, 1971, in the Adzhar ASSR. Ursolic acid was isolated by the successive extraction of the plant material with petroleum ether and chloroform. The chloroform residue $(2.3 \%)$ was treated with petroleum ether and was repeatedly recrystallized with the use of activated carbon from ethanol, giving finally a microcrystalline powder $(0.8 \%)$ with $\mathrm{mp}$ $278-280^{\circ} \mathrm{C}[\mathrm{a}]_{\mathrm{D}}^{18}+62.3^{\circ}$ (c 1.0 ; chloroform). A mixture of the substance obtained with an authentic sample of ursolic acid gave no depression of the melting point. On TLC [silica gel in the methanol-acetone $-\mathrm{CCl}_{4}(5$ : $20: 75)$ and toluene - ethyl acetate $-\mathrm{CH}_{3} \mathrm{COOH}(12: 4: 0.5)$ systems] it had mobilities similar to those of ursolic acid.

The IR spectrum of the substance isolated proved to be identical with that of standard ursolic acid [4].

\section{LITERATURE CITE D}

1. N. V. Belova, Rast. Res., $\underline{1}, 258$ (1968).

2. E. T. Oganesyan, Rast. Res., $\underline{4}, 516$ (1966).

3. N. V. Belova and G. A. Fokin, Khim. Prirodn. Soedin., 137 (1970).

4. G. Snatzke, F. Lampert, and R. Tschesche, Tetrahedron, $\underline{18}, 1417$ (1962).

I. G. Kutateladze Institute of Pharmacochemistry, Academy of Sciences of the Georgian SSR. Translated from Khimiya Prirodnykh Soedinenii, No. 2, p. 278, March-April, 1973. Original article submitted November 15, 1972.

(O) 1975 Plenum Publishing Corporation, 227 West 17th Street, New York, N.Y. 10011. No part of this publication may be reproduced, stored in a retrieval system, or transmitted, in any form or by any means, electronic, mechanical, photocopying, microfilming, recording or otherwise, without written permission of the publisher. A copy of this article is available from the publisher for $\$ 15.00$. 